\title{
IMPLICITATION IN TRANSLATION: EMPIRICAL EVIDENCE FOR OPERATIONAL ASYMMETRY IN TRANSLATION
}

\author{
KINGA KLAUDY $^{1}$ AND KRISZTINA KÁROLY ${ }^{2}$ \\ ${ }^{1}$ Interpreter and Translator Training Centre \\ Faculty of Humanities, Eötvös Loránd University \\ Múzeum krt. 4, Building "F", H-1088 Budapest, Hungary \\ Phone: +3614116500, Fax: +3614855217 \\ E-mail:kklaudy@ludens.elte.hu \\ ${ }^{2}$ Department of English Applied Linguistics \\ School of English and American Studies, Eötvös Loránd University \\ Ajtósi Dürer sor 19-21, H-1146 Budapest, Hungary \\ Phone: +36 14604421 , Fax: +3614604413 \\ E-mail:karolyk@ludens.elte.hu
}

\begin{abstract}
This study focuses on the notions of explicitation and implicitation in translation and aims to provide empirical evidence for operational asymmetry (Klaudy 2001). Bidirectional $\quad(\mathrm{SL}=\mathrm{L} 1 \rightarrow \mathrm{TL}=\mathrm{L} 2$ and $\mathrm{SL}=\mathrm{L} 2 \rightarrow \mathrm{TL}=\mathrm{L} 1)$ comparisons show that when explicitation takes place in the $\mathrm{L} 1 \rightarrow \mathrm{L} 2$ direction, implicitation can be observed in the $\mathrm{L} 2 \rightarrow \mathrm{L} 1$ direction. This phenomenon is referred to as symmetric explicitation. It may also happen, however, that when explicitation is carried out in the $\mathrm{L} 1 \rightarrow \mathrm{L} 2$ direction, no implicitation occurs in the $\mathrm{L} 2 \rightarrow \mathrm{L} 1$ direction. This phenomenon is referred to as asymmetric explicitation. It would be logical to suppose that all cases of language-specific explicitation in the $\mathrm{L} 1 \rightarrow \mathrm{L} 2$ direction are symmetrical (i.e., matched by implicitation in the $\mathrm{L} 2 \rightarrow \mathrm{L} 1$ direction), but this does not seem to be the case. The present paper reports on the findings of an empirical study designed to investigate the validity of the asymmetry hypothesis in the translation of reporting verbs in literary texts translated from English into Hungarian and from Hungarian into English. Using the method of two-way qualitative translation analysis, the study demonstrates that translators tend to prefer the more explicit forms to the more implicit ones in both directions and often fail to perform implicitation. The study may thus provide further evidence for the assumption that semantic explicitation is in fact a universal translation strategy.
\end{abstract}

Key words: implicitation, bi-directional comparison, operational asymmetry, two-way operations, one-way operations, asymmetric explicitation

\section{IMPLICITATION}

It is not an overstatement to suggest that the international body of literature on explicitation far overweighs the literature on implicitation. Implicitation is treated as a stepbrother of explicitation: it is generally mentioned merely incidentally. The marginal character of implicitation can be traced back to the beginnings of Translation Studies. Nida, in his 1964 book, introduces the section on "Subtractions" - one of the three "techniques of adjustment" - with the fol- 
lowing words: "Though, in translating, subtractions are neither so numerous nor varied as additions, they are nevertheless highly important in the process of adjustment" (Nida 1964:231). In his 1969 book, there is no separate chapter devoted to the techniques of adjustment, because they have become parts of the transfer stage, and the category of subtractions is left out completely.

In their glossary of terms, Vinay and Darbelnet define implicitation as "A stylistic translation technique which consists of making what is explicit in the source language implicit in the target language, relying on the context or the situation for conveying the meaning" (Vinay and Darbelnet 1995:344). Subsequently, they make the following remark: "Translators lengthen their texts out of prudence but also out of ignorance" (Vinay and Darbelnet 1995:193), which suggests that explicitation is not necessarily regarded as a positive phenomenon: sometimes it means that translators fail to perform necessary implicitation.

Research on the relationship between explicitation and implicitation belongs to the study of translation universals, that is, the universal characteristics of translated texts independent of language pair and direction of translation (Baker 1995, Laviosa 1998). Klaudy (2001) examined the relationship between explicitation and implicitation and their relationship to transfer operations in general on the basis of the analysis of literary works translated from Hungarian into English, German, French and Russian and vice versa. Based on the findings, she postulated the "asymmetry hypothesis", according to which explicitations in the $\mathrm{L} 1 \rightarrow \mathrm{L} 2$ direction are not always counterbalanced by implicitations in the $\mathrm{L} 2 \rightarrow \mathrm{L} 1$ direction because translators - if they have a choice - prefer to use operations involving explicitation, and often fail to perform optional implicitation (Klaudy 2001).

The present study is an attempt to provide initial data supporting the validity of the asymmetry hypothesis by exploring the behaviour of reporting verbs in translating from English into Hungarian and from Hungarian into English.

\section{INTERLINGUAL SYMMETRY AND ASYMMETRY}

The notion of interlingual symmetry and asymmetry was introduced into Translation Studies by the Russian scholar Vladimir Gak. He claimed that

the notions of symmetry and asymmetry in language can be applied not only to the relationships obtaining between signifier and signified within a certain language, but also to interlanguage relationships between two signifiers, as in the case of translation (Gak, in Zlateva 1993:33).

According to Gak, in translation, confrontation takes place between units of two different languages. These units can be of two types in their relationship 
to each other: (1) isomorphous units are in the relationship of interlanguage symmetry, (2) allomorphous units are in the relationship of interlanguage asymmetry.

The present study uses the concept of interlingual symmetry versus asymmetry in an entirely different sense, that is, in a dynamic rather than a static one. It investigates the symmetry and asymmetry of transfer operations using the method of bi-directional $(\mathrm{L} 1 \rightarrow \mathrm{L} 2$ and $\mathrm{L} 2 \rightarrow \mathrm{L} 1)$ comparison.

\section{DEFINING EXPLICITATION AND IMPLICITATION}

The terms explicitation and implicitation are used as defined by Klaudy (1998, 2003 ) as cover terms including a number of obligatory and optional transfer operations.

Explicitation takes place, for example, when a SL unit with a more general meaning is replaced by a TL unit with a more specific meaning; when the meaning of a SL unit is distributed over several units in the TL; when new meaningful elements appear in the TL text; when one sentence in the ST is divided into two or several sentences in the TT; or, when SL phrases are extended or "raised" to clause level in the TT, etc.

Implicitation occurs, for instance, when a SL unit with a specific meaning is replaced by a TL unit with a more general meaning; when translators combine the meanings of several SL words in one TL word; when meaningful lexical elements of the SL text are dropped in the TL text; when two or more sentences in the ST are conjoined into one sentence in the TT; or, when ST clauses are reduced to phrases in the TT, etc.

The standard transfer operations involving explicitation are the following: lexical specification, lexical division, lexical addition, grammatical specification, grammatical elevation (raising), grammatical addition. The standard transfer operations involving implicitation are the following: lexical generalisation, lexical contraction, lexical omission, grammatical generalisation, grammatical lowering (downgrading) and contraction, and grammatical omission (Klaudy 1998, 2003).

It would be tempting to assume that while transfer operations are automatic processes, explicitation and implicitation are always the results of translation strategies. (By transfer strategies we mean transfer operations carried out by translators consciously in order to transform the source language text into the target language text; Klaudy 2003:171). According to this hypothesis, translators tend to use explicitation strategies, while the use of implicitation strategies is typical of interpretation. This, however, is not true. Both explicitation and implicitation can be automatic operations or conscious strategies. The causes of both explicitation and implicitation can be language-specific and 
non-language-specific. Language-specific explicitations are not excluded from the current investigation as the bi-directional analysis of translations (form L1 to L2 and from L2 to L1) reveals an interesting operational asymmetry between obligatory explicitation in one direction and optional implicitation in the opposite direction.

\section{OBLIGATORY EXPLICITATION AND IMPLICITATION}

In the case of obligatory explicitation, the translator has no choice: if no explicitation is performed, the TT sentence will be ill-formed. Obligatory explicitations are necessitated by differences in the systems of the two languages involved. Obligatory explicitations are generally symmetrical, that is, explicitation in one direction is accompanied by implicitation in the other: such symmetrical operations are, for instance, the addition of articles in Russian-Hungarian translation and their omission in Hungarian-Russian translation; the distribution of the meaning components of synthetic Hungarian verb forms over several free morphemes in translating from Hungarian into Indo-European languages, and the incorporation of the meanings of auxiliaries into synthetic Hungarian verb forms in translating from Indo-European languages into Hungarian; the specification of grammatical gender in translating from Hungarian into Indo-European languages and generalization (neutralization of gender) in the opposite direction. The symmetrical nature of obligatory explicitation and implicitation is shown in Table 1.

\section{Table 1}

Obligatory explicitation and implicitation in Hungarian-English and English-Hungarian translation

\begin{tabular}{|c|c|c|}
\hline & Explicitation & Implicitation \\
\hline $\begin{array}{l}\text { Obligatory semantic } \\
\text { explicitation vs. } \\
\text { implicitation }\end{array}$ & $\begin{array}{l}\text { Specification of parts of the body } \\
\text { Direction: Hungarian-English } \\
\text { H: arc } \\
\text { E: face/cheek }\end{array}$ & $\begin{array}{l}\text { Generalisation of parts of the } \\
\text { body } \\
\text { Direction: English-Hungarian } \\
\text { E: face/cheek } \\
\text { H: arc } \\
\end{array}$ \\
\hline $\begin{array}{l}\text { Obligatory morpho- } \\
\text { logical explicitation vs. } \\
\text { implicitation }\end{array}$ & $\begin{array}{l}\text { Distribution of the meaning com- } \\
\text { ponents of verbs } \\
\text { Direction: Hungarian-English } \\
\text { H: megszólalt } \\
\text { E: began to speak }\end{array}$ & $\begin{array}{l}\text { Contraction of verbs } \\
\text { Direction: English-Hungarian } \\
\text { IE: began to speak } \\
\text { H: megszólalt } \\
\end{array}$ \\
\hline $\begin{array}{l}\text { Obligatory grammati- } \\
\text { cal explicitation vs. } \\
\text { implicitation }\end{array}$ & $\begin{array}{l}\text { Specification of gender } \\
\text { Direction: Hungarian-English } \\
\text { H: belépett } \\
\text { E: she entered }\end{array}$ & $\begin{array}{l}\text { Generalisation (neutralisation) } \\
\text { of gender } \\
\text { Direction: English-Hungarian } \\
\text { E: she entered } \\
H: \text { belépett }\end{array}$ \\
\hline
\end{tabular}


Some asymmetry may be observed even in cases of obligatory explicittation. An interesting form of asymmetry can be detected between the addition and omission of some grammatical items. The addition of personal pronouns, pronominal objects and the present tense forms of the existential verb are regarded as automatic and obligatory transformation operations in translating from Hungarian into English, because in the latter case these items are indispensable in grammatically well-formed sentences.

If, however, we investigate the omission of the same items in translating from English into Hungarian, what we see is that it is only the present tense form of the existential verb that will automatically disappear from the Hungarian translation. The omission of personal pronouns and pronominal objects does not appear to be a completely automatic process; novice translators often fail to carry out these operations (Klaudy and Károly 2004).

\section{OPTIONAL EXPLICITATION AND IMPLICITATION}

In the case of optional explicitation, the translator is faced with a choice: $\mathrm{s} / \mathrm{he}$ may produce a well-formed target language sentence even without carrying out explicitation. In this case explicitation is generally not necessitated by linguistic differences, but by differences in language use, discourse structure, and background information. Optional explicitation in one direction may also be in a

Table 2

Optional explicitation and implicitation in Hungarian-English and English-Hungarian translation

\begin{tabular}{|l|l|l|}
\hline & Explicitation & Implicitation \\
\hline $\begin{array}{l}\text { Optional } \\
\text { semantic } \\
\text { explicitation vs. } \\
\text { implicitation }\end{array}$ & $\begin{array}{l}\text { Specification of reporting verbs } \\
\text { Direction: English-Hungarian } \\
\text { E: said } \\
\text { H: } \text { morogta (murmured) }\end{array}$ & $\begin{array}{l}\text { Generalisation of reporting verbs } \\
\text { Direction: Hungarian-English } \\
\text { H: } \text { morogta (murmured) } \\
\text { E: said }\end{array}$ \\
\hline $\begin{array}{l}\text { Optional } \\
\text { syntactic } \\
\text { explicitation vs. } \\
\text { implicitation }\end{array}$ & $\begin{array}{l}\text { Elevation (raising) of participial and } \\
\text { infinitival phrases to clause level }\end{array}$ & $\begin{array}{l}\text { Lowering (downgrading) of } \\
\text { clauses to phrase level }\end{array}$ \\
\hline $\begin{array}{l}\text { Optional } \\
\text { discourse-level } \\
\text { explicitation vs. } \\
\text { implicitation }\end{array}$ & $\begin{array}{l}\text { Direction: English-Hungarian } \\
\text { phasis, or addition of theme/rheme } \\
\text { boundary markers } \\
\text { Direction: }(-)\end{array}$ & $\begin{array}{l}\text { Omission of elements expressing } \\
\text { emphasis, or omission of } \\
\text { theme/rheme boundary markers } \\
\text { Direction: }(-)\end{array}$ \\
\hline $\begin{array}{l}\text { Optional } \\
\text { pragmatic } \\
\text { explicitation vs. } \\
\text { implicitation }\end{array}$ & $\begin{array}{l}\text { Addition of explanation in translating } \\
\text { institutional and geographical names }\end{array}$ & $\begin{array}{l}\text { Omission of explanation in trans- } \\
\text { lating institutional and geographi- } \\
\text { cal names } \\
\text { Direction: }(-)\end{array}$ \\
\hline
\end{tabular}


symmetrical relationship with implicitation in the opposite direction, as shown in Table 2; however, due to its optionality, optional explicitation in one direction is not always matched by optional implicitation in the opposite direction.

In the case of optional explicitation, asymmetry is very frequent. A typical form of explicitation in English-Hungarian translation is the "unpackaging" of infinitival and participial phrases, that is, raising them to clause level. This operation, as mentioned above, is optional, since extended infinitival and participial phrases are also possible in Hungarian. Still, translators often opt for the more explicit, longer solutions. However, if we examine this operation in the opposite direction, i.e., the downgrading of Hungarian clauses to infinitival and participial phrases in translations from Hungarian into English, we can see that translators frequently fail to perform this operation. In other words, explicitation in one direction does not necessarily entail implicitation in the other direction.

\section{THE CONCEPT OF OPERATIONAL SYMMETRY/ASYMMETRY IN TRANSLATION}

Operational symmetry and asymmetry refer to the symmetrical or asymmetrical relationship between transfer operations from a specific ST to a specific TT and vice versa. Operational symmetry exists when explicitation takes place in one direction, while implicitation occurs in the opposite direction. Thus, for example, specification (addition) of personal pronouns in translating from Hungarian into English and generalisation (omission) of personal pronouns in the opposite direction seem to exemplify operational symmetry. Operational asymmetry appears when explicitation in one direction is not counterbalanced (paralleled) by implicitation in the opposite direction. Thus, for example, the elevation (raising) of phrases to clause level in translating from English into Hungarian is not counterbalanced by the lowering (downgrading) of clauses to phrase level in translating from Hungarian into English.

\section{EMPIRICAL EVIDENCE FOR THE ASYMMETRY HYPOTHESIS}

\subsection{Rationale for the Analytical Approach}

To prove the asymmetry hypothesis, empirical research must involve specific language pairs in both translation directions. The current study is intended as a first step in this process, exploring the behaviour of reporting verbs in a bidirectional, English/Hungarian corpus. 
The study merges the quantitative analysis with a qualitative approach, as in this case a purely quantitative investigation, i.e., simple word count alone does not demonstrate the asymmetry between explicitation and implicitation. If a synthetic language (such as Hungarian) is compared to an analytic one (such as English), the number of words will always be higher in the analytic language (in this case, English) irrespective of the translation direction. Furthermore, as explained earlier, the addition of elements to the target language text that are not present in the source language text is not the only form of explicitation; the other forms of explicitation, such as semantic enrichment or disambiguation of sentence structure do not manifest themselves in an increase in the number of words.

Therefore, to test the validity of the hypothesis, two-way qualitative translation analyses are needed involving different language pairs in order to explore language-specific and translation-specific explicitation. Two-way operations (which can also be called "reciprocal" operations), in which distribution in one direction is matched by contraction in the other, or specification in one direction is matched by generalisation in the other, etc. must be treated separately from one-way operations, which appear only in translating from a given source language to a given target language.

The current bi-directional investigation is designed to provide empirical evidence for the phenomenon where optional semantic specification (i.e., explicitation) in one direction is not paralleled by generalisation (i.e., implicitation) in the opposite direction.

\subsection{Texts Submitted to Analysis}

The corpus submitted to analysis consists of three novels and their respective Hungarian/English translations:

Text 1: English ST - Orwell: 1984 and its Hungarian translation

Text 2: Hungarian ST - Kosztolányi: Édes Anna and its English translation (Anna Édes)

Text 3: Hungarian ST - Mikszáth: Szent Péter esernyojje and its English translation (St. Peter's Umbrella).

These novels were selected because they represent regular, modern language use, contain a sufficient number of dialogues for the analysis of reporting verbs and portray no features that could distort the results. The analysis focuses on the investigation of 100 reporting verbs and their translations from a randomly selected part of each novel, which adds up to 600 reporting verbs altogether. 


\subsection{Procedures of Analysis}

The analysis aims to explore the variability of the reporting verbs in the different texts. Variability is approached from two different angles: (1) looking at the number of different reporting verbs (type) vs. the total number of reporting verbs (token), and (2) looking at the number of reporting verbs occurring once vs. the total number of reporting verbs. The first count is referred to as Variability Index 1, whereas the latter is referred to as Variability Index 2 (see Table 3). These counts are intended to reveal patterns in the way in which translators deal with this verb type in the two translation directions, which may yield an answer to the question whether translators' explicitation in the English-Hungarian direction is paralleled by implicitation (simplification) in the Hungarian-English direction.

\subsection{Results and Discussion}

The results of the variability analysis are presented in Table 3 . The figures show that in the English-Hungarian direction translators do perform explicitation, as shown by the considerable increase in the type/token ratio (from 0.14 to 0.32 ). In the opposite (Hungarian-English) direction, however, where implicitation could be expected as a result of operational symmetry, there seems to be no simplification: in the case of Anna Édes, the type-token ratio remains just as high in the English translation as in the Hungarian ST (0.56), and in the case of St. Peter's Umbrella it shows only a slight, inconsiderable decrease from 0.27 to 0.24 . This means that, contrary to expectations, translators do not opt for simplification in translating into English: instead, they will tend to preserve the rich variety of reporting verbs in the Hungarian ST.

The same pattern may be observed in the case of Variability Index 2 (Table 3 ), which portrays the ratio of reporting verbs occurring once vs. the total number of reporting verbs in the sample: the marked increase in the EnglishHungarian direction (from 0.08 to 0.18 ) is not counterbalanced by a similar decrease in the Hungarian-English direction (there is only a slight drop from 0.47 to 0.42 in the case of Anna Édes and from 0.17 to 0.12 in the case of St. Peter's Umbrella), which shows that the extent of the increase in the English-Hungarian direction is not paralleled by a decrease of the same extent in the Hungarian-English direction. Therefore it may be argued that the results obtained for both variability indices underpin the validity of the asymmetry hypothesis.

To graphically represent the findings, the reporting verbs of the six samples have been listed below in decreasing order of frequency (Tables 4-9). The verbs appear in their dictionary forms; the English dictionary equivalents of the Hungarian verbs are given in brackets, and frequency of occurrence in the 100verb sample is indicated in the right-hand columns. 
Table 3

Results of the variability analysis

\begin{tabular}{|l|c|cc|cc|}
\hline & & \multicolumn{2}{|c|}{ Variability Index 1 } & \multicolumn{2}{c|}{ Variability Index 2 } \\
\cline { 2 - 6 } & $\begin{array}{c}\text { Total of } \\
\text { RVs }\end{array}$ & $\begin{array}{c}\text { Different } \\
\text { RVs }\end{array}$ & $\begin{array}{c}\text { Type/ } \\
\text { token }\end{array}$ & $\begin{array}{c}\text { RVs } \\
\text { occurring } \\
\text { once }\end{array}$ & $\begin{array}{c}\text { RVs occurring } \\
\text { once/ } \\
\text { Total of RVs }\end{array}$ \\
\hline $\begin{array}{l}\text { English ST: } \\
\begin{array}{l}\text { Orwell: 1984 } \\
\text { Hungarian TT: }\end{array}\end{array}$ & 100 & 14 & 0.14 & 8 & 0.08 \\
$\begin{array}{l}\text { Orwell: 1984 } \\
\text { Hungarian ST: }\end{array}$ & 100 & 32 & 0.32 & 18 & 0.18 \\
$\begin{array}{l}\text { Kosztolányi: Édes Anna } \\
\text { English TT: }\end{array}$ & 100 & 56 & 0.56 & 47 & 0.47 \\
$\begin{array}{l}\text { Kosztolányi: Anna Édes } \\
\text { Hungarian ST: }\end{array}$ & 100 & 56 & 0.56 & 42 & 0.42 \\
$\begin{array}{l}\text { Mikszáth: Szent Péter esernyője } \\
\text { English TT: } \\
\text { Mikszáth: St. Peter's Umbrella }\end{array}$ & 100 & 27 & 0.27 & 17 & 0.17 \\
\hline
\end{tabular}

Abbreviation: $\mathrm{RVs}=$ reporting verbs

It is important to note that in Anna Édes and St. Peter's Umbrella, not all reporting verbs had direct equivalents in the translation. Both the translation and the ST had a few missing or a few additional verbs. Thus, for instance, a Hungarian verb in the ST was not always translated by an English verb, and vice versa. Hence the "missing verb" category in some of the tables.

\section{Table 4}

George Orwell: 1984 - English ST

\begin{tabular}{rlr} 
1. & say & 79 \\
2. & whisper & 4 \\
3. & murmur & 3 \\
4. & add & 2 \\
5. & yell & 2 \\
6. & begin & 2 \\
7. & agree & 1 \\
8. & cry & 1 \\
9. & persist & 1 \\
10. & grumble & 1 \\
11. & put in & 1 \\
12. & supplement & 1 \\
13. & go on & 1 \\
14. & repeat & 1 \\
\hline$\sum$ & & 100
\end{tabular}


As Tables 4 and 5 show, the 100 reporting verbs (tokens) of the English source text consist of 14 different reporting verbs (types), while the 100 reporting verbs (tokens) of the Hungarian target text include 32 different reporting verbs (types). The increasing type/token ratio $(0.14<0.32)$ indicates that the Hungarian translator used more specific verbs than the author of the source text, i.e., resorted to explicitation of the meaning implied in the English original.

\section{Table 5}

George Orwell: 1984 - Hungarian TT

1. felel (answer)

2. kérdez (ask)

3. megállapít (remark)

4. kijelent (state)

5. mond (say)

6. kezd (begin)

7. megjegyez (comment)

8. megszólal (speak)

9. kiált (shout)

10. mormol (murmur)

11. suttog (whisper)

12. közöl (tell)

13. hozzátesz (add)

14. folytat (continue)

15. visszatér (return)

16. oldalba bök (nudge)

18
14
10
10
4
4
4
3
3
3
3
2
2
2
1
1

\begin{tabular}{llr} 
17. & helyesel (approve) & 1 \\
18. & üvölt (yell) & 1 \\
19. & makacskodik (insist) & 1 \\
20. & odavet (drop a remark) & 1 \\
21. & közbevet (intervene) & 1 \\
22. & dörmög (mutter) & 1 \\
23. & tapogatózik (enquire gently) & 1 \\
24. & kap a szón (seize the word) & 1 \\
25. & közbeszól (intervene) & 1 \\
26. & ajánl (recommend) & 1 \\
27. & magyaráz (explain) & 1 \\
28. & felfigyel (take note) & 1 \\
29. & bong (ring) & 1 \\
30. & megismétel (repeat) & 1 \\
31. & visszasúg (whisper back) & 1 \\
32. & kinyilatkoztat (reveal) & 1 \\
\hline$\sum$ & & 100
\end{tabular}

The choice of more specific verbs in translation is evidently not accidental: the source of semantic explicitation is meaning implied in the ST. The specification of reporting verbs may take several forms in English $\rightarrow$ Hungarian translation (as described in Klaudy 2003:191-195).

(1) In the simplest case, Hungarian translators also use reporting verbs, but more specific and less frequent ones, applying a variety of Hungarian verbs of saying instead of the correspondents of the central verb say: felel ('answer'), kérdez ('ask'), megállapit ('remark'), kijelent ('state').

(2) Instead of simply indicating that something has been said, translators often refer to the permanent or occasional characteristics of the speech of individual speakers (tone, rate, emphasis), using verbs that lie even farther away from the centre of the semantic field of verbs of saying: hebeg ('to stammer'), dadog ('to stutter'), hadar ('to gabble'), makog ('to falter'), suttog ('to whisper').

(3) In specifying English reporting verbs, Hungarian translators frequently use verbs which, in addition, also reflect the speaker's state of mind and emotions: hüledezik ('to be dumbfounded'), csodálkozik ('to be astonished'), meg- 
lepödik ('to be surprised'). In such cases, the translator's decision is influenced by the whole communicative situation described in the given literary work. When choosing emotionally loaded verbs instead of simple verbs of saying, translators rely on their knowledge of the situation, the speaker's state of mind, their emotions towards each other, etc.

(4) Among Hungarian reporting verbs, we frequently find verbs indicating bodily movements that commonly accompany the act of speaking: bólint ('to nod'), legyint ('to wave a hand to signal indifference'), felkapja a fejét ('to toss up one's head').

(5) Finally, in order to specify reporting verbs, translators may use verbs that reflect the act of speaking only by virtue of the situation. Such verbs express a change in place or bodily position: leül ('to sit down'), feláll ('to stand up'), belép a szobába ('to enter the room').

\section{Table 6}

Kosztolányi Dezső: Édes Anna - Hungarian ST

\begin{tabular}{|c|c|}
\hline 1. mond (say) & 1 \\
\hline 2. szól (say/utter) & \\
\hline 3. kérdez (ask) & \\
\hline 4. suttog (whisper) & \\
\hline 5. válaszol (respond) & \\
\hline 6. megszólal (speak) & \\
\hline 7. ismétel (repeat) & \\
\hline 8. felel (answer) & \\
\hline 9. kijavít (correct) & \\
\hline 10. dörmög (mutter) & \\
\hline 11. hozzátesz (add) & \\
\hline 12. harsog (resound) & \\
\hline 13. üdvözöl (greet) & \\
\hline 14. lelkendez (enthuse) & \\
\hline 15. hümmög (hum) & \\
\hline 16. hebeg (stutter) & \\
\hline 17. mutat (show) & \\
\hline 18. mosolyog (smile) & \\
\hline 19. hajlong (bow) & \\
\hline 20. újságol (inform) & \\
\hline 21. rárivall (scold) & \\
\hline 22. kifakad (burst out) & \\
\hline 23. tódít (exaggerate) & \\
\hline 24. érdeklődik (enquire) & \\
\hline 25. helyben hagy (agree) & \\
\hline 26. faggat (interrogate) & \\
\hline 27. folytat (continue) & \\
\hline $\begin{array}{l}\text { 28. megragadja a szót } \\
\text { (seize the word) }\end{array}$ & \\
\hline
\end{tabular}

\begin{tabular}{|c|c|c|}
\hline 29. & sápítozik (lament) & 1 \\
\hline 30. & kesereg (grieve) & 1 \\
\hline 31. & odavet (drop a remark) & 1 \\
\hline 32. & gúnyol (make fun of) & 1 \\
\hline 33. & tűnődik (ponder) & 1 \\
\hline 34. & kijelent (state) & 1 \\
\hline 35. & kitör (burst out) & 1 \\
\hline 36. & hangsúlyoz (emphasise) & 1 \\
\hline 37. & sóhajt (sigh) & 1 \\
\hline 38. & unszol (press/urge) & 1 \\
\hline 39. & tessékel befelé (usher in) & 1 \\
\hline 40. & csitít (hush) & 1 \\
\hline 41. & magyaráz (explain) & 1 \\
\hline 42. & ásít (yawn) & 1 \\
\hline 43. & tartóztat (keep from going) & 1 \\
\hline 44. & csodálkozik (marvel) & 1 \\
\hline 45. & szemrehányást tesz (retort) & 1 \\
\hline 46. & nyugtat (reassure) & 1 \\
\hline 47. & erősít (insist) & 1 \\
\hline 48. & fordul hozzá (turn to) & 1 \\
\hline 49. & olvas (read) & 1 \\
\hline 50. & szerénykedik (behave modestly) & 1 \\
\hline 51. & firtat (keep asking) & 1 \\
\hline 52. & menteget (find excuse) & 1 \\
\hline 53. & siet (hurry) & 1 \\
\hline 54. & bíztat (encourage) & 1 \\
\hline 55. & dicsekedik (boast) & 1 \\
\hline & utasít (command/instruct) & 1 \\
\hline Mis & ng verb & 7 \\
\hline
\end{tabular}


Searching for the reasons motivating this kind of semantic explicitation, it may be claimed that the rich morphological potential offered by the Hungarian language provides ample opportunity for specification; but this is only an option. English verbs of general meaning always have, or may have, a corresponding Hungarian verb with a similarly general meaning. Use of a semantically depleted verb in Hungarian (dictionary equivalent) would not violate any of the norms of the Hungarian language. Thus, the explicitation of English verbs in English-Hungarian translation is an optional transfer operation. The fact that the majority of professional translators tend to specify English verbs of saying shows that beside the TL norm there is a tendency to also follow the translational norms at the same time.

Authors of original Hungarian texts, of course, heavily rely on the ability of Hungarian verbs to incorporate a great amount of grammatical and lexical information within a single verb form. If translators intend to produce a Hungarian text, the language of which is not less colourful and less expressive than that of the original, they must utilise the potential of Hungarian verb formation. Let us remark in passing that one reason for translationese is exactly this inadequate utilisation of the linguistic resources of the TL. Using more specific Hungarian verbs in translation is a way to avoid translationese.

Table 6 illustrates the rich inventory of reporting verbs in an original Hungarian text, that is, in the novel Anna Édes, written by Dezső Kosztolányi. In this novel the type/token ratio is 0.56 (100 tokens of Hungarian reporting verbs consist of 56 different types). As authors of original English texts prefer to use the central verbs of the semantic field of verbs of saying, the number of different verbs should have decreased in the English translation of the Hungarian novel. This, however, did not happen. As it can be seen in Table 7, the semantic richness of reporting verbs was preserved in the English translation, and the type/token ratio remained the same (0.56) in the translated English text as in the original Hungarian novel (0.56).

A similar phenomenon can be observed in the following example, which illustrates the change in type/token ratio of reporting verbs in the English translation of another Hungarian literary piece: in the novel by Kálmán Mikszáth, Szent Péter esernyöje (St. Peter's Umbrella). As Tables 8 and 9 show, there is almost no decrease in the type/token ratio of the reporting verbs in English translation $(0.27>0.24)$, which means that the rich variety of reporting verbs in the Hungarian original is preserved in the English translation, that is, the translator, again, failed to perform semantic implicitation.

The tables demonstrate that Hungarian uses a wider variety of reporting verbs (i.e. a higher number of verbs occurring once) in both translated and original Hungarian texts. The increasing variety of reporting verbs in the Hungarian translation of Orwell's novel $(0.24<0.32)$ proves that the translator often resorted to explicitation, using more specific reporting verbs to express mean- 
ings implied in the context. In contrast, the preserved or hardly decreasing variety of reporting verbs in the English translation of Kosztolányi's and Mikszáth's novels $(0.56=0.56$ and $0.27>0.24$ respectively) proves that translators did not resort to implicitation, and did not use more general reporting verbs in translated English texts.

\section{Table 7}

Dezső Kosztolányi: Anna Édes - English TT
1. ask
2. answer
3. say
4. repeat
5. add
6. whisper
7. smile
8. sigh
9. hesitate
10. speak
11. mimick
12. correct
13. assure
14. reply
15. growl
16. bellow
17. respond
18. enthuse
19. murmur
20. pronounce
21. stutter
22. announce
23. begin
24. yell
25. burst out
26. continue
27. rumble
28. enquire

\begin{tabular}{llr}
$29 . \quad$ nag & 1 \\
$30 . \quad$ leap & 1 \\
$31 . \quad$ lament & 1 \\
$32 . \quad$ mutter & 1 \\
$33 . \quad$ ponder & 1 \\
$34 . \quad$ exclaim & 1 \\
$35 . \quad$ retort & 1 \\
$36 . \quad$ insist & 1 \\
$37 . \quad$ emphasise & 1 \\
$38 . \quad$ urge & 1 \\
$39 . \quad$ press & 1 \\
$40 . \quad$ plead & 1 \\
$41 . \quad$ suggest & 1 \\
$42 . \quad$ yawn & 1 \\
$43 . \quad$ delay & 1 \\
$44 . \quad$ marvel & 1 \\
$45 . \quad$ mouth & 1 \\
$46 . \quad$ pester & 1 \\
$47 . \quad$ bow & 1 \\
$48 . \quad$ call & 1 \\
$49 . \quad$ confirm & 1 \\
$50 . \quad$ turn to & 1 \\
$51 . \quad$ quote & 1 \\
52. & declare & 1 \\
53. & hasten & 1 \\
$54 . \quad$ hurry & 1 \\
$55 . \quad$ boast & 1 \\
56. & instruct \\
Missing verb & 1 \\
\hline$\sum$ & & 9 \\
\hline & &
\end{tabular}

It is interesting to observe the striking difference between the frequency of the word 'say' in Orwell's 1984 (English ST: 79 occurrences) and in Anna Édes's English translation (English TT: 5 occurrences). This also reflects the phenomenon that while Hungarian tends to use the peripheral verbs in the semantic field of reporting, English opts for the more central verbs. Instead of following this preference for the more central lexical item and performing generalisation when translating from Hungarian into English, translators tend to preserve the semantically more specific verbs, and thus there will be no simplification/implicitation matching explicitation in the opposite direction. 
Table 8

Mikszáth Kálmán: Szent Péter esernyöje - Hungarian ST

1. mond (say)

2. kiált (call out/shout)

3. $\quad$ kérd (ask)

4. szól (say/utter)

5. felel (answer)

6. megjegyez (remark)

7. felsóhajt (sigh)

8. hozzáteszi (add)

9. ismétel (repeat)

10. gondol (think)

11. ellenvet (object)

12. eldönt (decide)

13. humorizál (make fun)

14. tódít (exaggerate)

15. dadog (stammer)

16. tünődik (ponder)

17. terjeszt eléje (put forward)

18. mormog (murmur)

19. felpattan (thunder out)

20. ötöl-hatol (ponder)

21. összecsapja a kezét (clap hands)

22. könyörög (beg)

23. nyilatkozik (declare)

24. csitítgat (calm down)

25. ellenkezik (disagree)

26. nyöszörög (moan)

27. szemrehány (rebuke)

Missing verb

$\Sigma$

$$
\text { verb }
$$

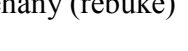

e)

(a)

Table 9

Kálmán Mikszáth: St. Peter's Umbrella - English TT

$\begin{array}{rlrlll}\text { 1. } & \text { say } & 38 & 13 . & \text { thunder out } & 1 \\ 2 . & \text { answer } & 8 & 14 . & \text { rebuke } & 1 \\ 3 . & \text { exclaim } & 7 & 15 . & \text { sigh } & 1 \\ \text { 4. } & \text { ask } & 4 & 16 . & \text { stammer } & 1 \\ 5 . & \text { remark } & 4 & 17 . & \text { grumble } & 1 \\ 6 . & \text { think } & 4 & 18 . & \text { reply } & 1 \\ 7 . & \text { call out } & 3 & 19 . & \text { burst out } & 1 \\ 8 . & \text { add } & 3 & 20 . & \text { beg } & 1 \\ 9 . & \text { shout } & 3 & 21 . & \text { whisper } & 1 \\ 10 . & \text { repeat } & 3 & 22 . & \text { pray } & 1 \\ 11 . & \text { begin } & 2 & 23 . & \text { quote } & 1 \\ 12 . & \text { murmur } & 2 & 24 . & \text { moan } & 1 \\ & & & \text { Missing verb } & & 100\end{array}$




\subsection{Theoretical Implications}

By finding evidence for the asymmetry hypothesis, it may become possible to prove that explicitation is indeed a universal feature of translation. It has long been debated whether explicitation is a language-pair-dependent phenomenon, or one that is independent of the given language pair and is thus universal. If it is a universal phenomenon, then explicitation in one direction cannot be matched by implicitation in the other. If it depends on the given language pair, then we do not get to know much more about the typical behaviour of translators. If, however, we can identify a special group of cases where explicitation occurs in translation from a given source language into a given target language without implicitation occurring in the opposite direction, then we have succeeded in identifying a language-pair-independent universal feature of translator behaviour.

\section{CONCLUSION}

This study aimed to provide initial data for the empirical verification of the asymmetry hypothesis. In the light of the data from the bi-directional corpus used in this study, it may be concluded that translators prefer the more extended, more explicit forms to the more reduced, more implicit forms, and often fail to perform implicitation. Further research is, however, needed, involving larger corpora and a wider array of explicitation phenomena to provide a more reliable and generalizable account of the validity of the asymmetry hypothesis. Should this hypothesis be verified, it would underpin the assumption that explicitation is in fact a universal strategy of translation, independent of languagepair and direction of translation.

\section{References}

Baker, M. 1995. Corpora in Translation Studies. An Overview and Suggestions for Future Research. Target Vol. 7. No. 2. 223-245.

Gak, V. 1993. Interlanguage Asymmetry and the Prognostication of Transformations in Translation. In: Zlateva, P. (ed.) Translation as Social Action. London: Routledge. 32-39.

Klaudy, K. 1998. Explicitation. In: Baker, M. (ed.) Encyclopedia of Translation Studies. (ed.) London: Routledge. 80-85.

Klaudy, K. 2001. The Asymmetry Hypothesis. Testing the Asymmetric Relationship between Explicitations and Implicitations. Paper presented at the Third International Congress of the European Society for Translation Studies, "Claims, Changes and Challenges in Translation Studies", 30 August-1 September 2001, Copenhagen.

Klaudy, K. 2003. Languages in Translation. Lectures on the Theory, Teaching and Practice of Translation. With Illustrations in English, French, German, Russian and Hungarian. Budapest: Scholastica. 
Klaudy, K. \& Károly, K. 2004. Unperformed Omissions? Paper presented at the Fourth International Congress of the European Society for Translation Studies, "Translation Studies: Doubts and Directions", 27-29 September 2004, Lisbon.

Laviosa, S. 1998. Universals in Translation. In: Baker, M. (ed.) Encyclopedia of Translation Studies. London: Routledge. 288-291.

Nida, E. A. 1964. Toward a Science of Translating. Leiden: Brill.

Nida, E. A. \& Taber, Ch. R. 1969. The Theory and Practice of Translation. Leiden: Brill.

Vinay, J. P. \& Darbelnet, J. 1995. Comparative Stylistics of French and English. A Methodology for Translation. Amsterdam: John Benjamins. Translated by J. C. Sager and M. J. Hamel. 